\title{
ANQUILOGLOSSIA: PREVALÊNCIA ENTRE CRIANÇAS DE 0 A 18 MESES ATENDIDAS EM UMA UNIDADE DE SAÚDE DO MUNICÍPIO DE COLOMBO
}

Giselle MELO; Fernanda Isam ISA; Norma Suely Falcão de Oliveira MELO.

O freio lingual é uma membrana mucosa aderida desde a base da língua até o rebordo alveolar. Esta estrutura no recém-nascido tem uma atuação importante no ato de sucção e amamentação. Um freio lingual curto dificulta os movimentos da língua e pode se apresentar bastante aderido ao assoalho da cavidade bucal. Este aspecto patológico é chamado anquiloglossia. Este estudo tem por objetivo avaliar a prevalência de anquiloglossia em crianças, na faixa etária de 0 a 18 meses, atendidas em uma Unidade de Saúde de Colombo no período março a setembro de 2007. A amostra constou de 64 crianças na faixa etária de 0 a 18 meses, sendo 25 meninas e 39 meninos participantes do programa de atenção à criança do Município de Colombo. $O$ atendimento odontológico foi realizado no período de espera da consulta do pediatra. Através de um exame bucal foi estabelecido o diagnóstico de anquiloglossia. Os resultados mostraram uma prevalência de $6,3 \%$ de anquiloglossia nas crianças examinadas. A prevalência entre os meninos foi de $8 \%$ e nas meninas de $4 \%$. Concluiu-se que a anquiloglossia quando associada às alterações de sucção pode interferir no aleitamento materno ou na fala, fato que ocorreu em $4 \%$ das crianças examinadas. 